\title{
The Impact of the Policy of Đổi Mói (1986) and Neoliberalism on the Internationalization of Higher Education in Vietnam
}

\author{
Brooke Bách-Tầng Phan \\ Global Education Collaborative@UCLA \\ (Available from: https://www.uclagec.org/)
}

In December of 1986, the Communist Party of Vietnam (CPV) convened at the 8th National Congress and adopted the Policy of Renovation or Đổi Mơ i-a tacit acknowledgement that the centrally planned economy in which the unified country has adopted since 1975, had failed. The results of Đổi Mơ itransforming a market-based economy within the framework of a socialist government-were immediate and spectacular. Hyperinflation went down from $775 \%$ in 1986 (Vuong, 2014) to the single digits a decade later (ADB, 1999). GDP per capita tripled from US\$100 in 1987 to UD\$300 in 1996 (ADB, 1999). The New York Times declared Vietnam as Asia's 'Economic Miracle' in 1990 (Weinglass, 1990), a term for which the World Economic Forum said the same in 2018 (Vanham, 2018), showing economic momentum had sustained throughout the 1990 and 2000s.

Long before this 'economic miracle', plans to expand higher education, recognized as a crucial contribution to the nation's economic renovation, had been considered toward the end of war in 1975 (Dang, 2009). To illustrate: during the 1974-1975 academic year, there were 41 higher education institutions (HEIs) with 100 different disciplines, serving 55,700 students and 8,658 teaching staff (MOET, 2004). Five years later (1980-1981 academic year), the country had increased the number of HEIs: 85 public universities/ colleges and 33 junior public colleges, with 146,000 students and 17,300 academic staff (MOET, 2004). Expanding higher education further, two new degrees were added in 1976: phó tiê n sỹ (associate doctoral degree) and tiến sỹ (doctoral degree). Two different levels of professorships were also added in 1980: phó giáo su' (associate professor) and giáo su' (professor). Yet goals for growth and expansion were undermined by the decade of post-war economic crisis.

Following the enactment of Đổi Mớ $\mathrm{i}$ alongside rising levels of ambition and optimism, the nation pursued a course of heavy industrialization and rapid modernization. Within the education sector, the Ministry of Education and Training (MOET) pursued educational policies to reform to develop sustainable manpower and continual economic development (MOET, 2002). Deregulation, privatization and economic liberalization policies coincided with consumer demand fueling the expansion and diversification of higher educational institutions (HEIs). In 1991, only $2 \%$ of the university-aged adults had studied at 
the university level. But by 1999, this figure increased significantly to 11\% (Pham \& Fry, 2004). Net enrollment ratio steadily climbed each year to $28.6 \%$ in the year 2016 (UNESCO Institute of Statistics, 2018). Universities diversified their options further, allowing for more professional and terminal masters degree programs to educate and train skilled workers (MOET, 2004). The MOET also encouraged higher educational institutions to form stronger links to business and industry (Harman et al., 2010). Overall, HEIs proliferated; by 2007, there were 345 HEIs of which 288 are public and 57 are private, accounting for almost two million students (MOET, 2004).

As the number of HEIs expanded and diversified study options to meet growing demand, Vietnamese educational policy---at both the national and institutional levels--followed the path of internationalizing higher education. The reasons for this, as Lane (2015) and Knight (2008) observed, are necessary for nation building-strategic alliances, public diplomacy, and economic competitivenessand institutional goal setting-prestige, branding, foster innovation and economic competitiveness. Internationalization of higher education in Asia in particular, has been categorized into different modalities: import-oriented, import and export, and transitional (Huang, 2007 in Hoang et al., 2018, p. 2223), using economic metaphors to understand the direction of transmission and reception of institutional knowledge, pedagogical practices and policies. Vietnam's form of internationalization in higher education, like Indonesia, occurs mostly through the importation of foreign educational programs and institutions, particularly from Western countries in order to advance standards and quality to other higher education systems (Huang, 2007 in Hoang et al., 2018, p. 22-23).

Two large policy measures have been most attributed to this change: the passage of the Higher Education Reform Agenda, 2006-2020, upon recommendation by the World Bank in 2006 and at the 2oth anniversary of Đổi Mơ i during the 1oth National Congress (Hoang et al., 2018, p. 24-25), and Decree 73/2012ND-CP, which took effect in November 2012 (Australian Education International Vietnam, 2013). Though Decree 73 applies to a broad range of educational reform at all levels of education in Vietnam, the impact on higher education show a clear direction toward internationalization such as the creation of foreign universities' branch campuses, lowered barriers to foreign direct investment, twinning and joint university programs, permissibility of representative offices of foreign education institutions and, the removal of limitation on the percentage of Vietnamese students in foreign HEIs (Hoang et al, 2018, p. 26; Australian Education International Vietnam, 2013, p. 3).

The strategic policy of HERA 2006-2020, passed in Resolution Number 14/2005/NQ-CP on November 2, 2005, was to build the nation's socio-economic development goals; two of which is to prepare a workforce in a knowledge economy and global economic integration (Hoang et al., 2018, p. 23). This 
neoliberal policy, ironically, was written à là Soviet-style, in three 'five-year phases'. In the first set of three five-year plans (2006-2010), HERA prioritized measures to improve quality of instruction in higher educational institutions: content training, building renovation, management and human resource allocation (World Bank, 2008). The second 'five-year' phase (2011-2015) built on the momentum of the first phase, primarily in terms of quality of instructors and managers, coming closer to regional and international standards (World Bank, 2008). Lastly, in the third phase (2016-2020), the HEI would've implemented the structure and framework for a modern higher educational system (World Bank, 2008). HERA intends to expand in every scope: more doctoral qualified professors, more student enrollment, more research and innovation, more connections to private businesses and international universities. What this means that the brunt of these changes, must actualize in the public sector of higher education where $83 \%$ of higher education student enrollment is enrolled in public HEIs (World Bank, 2008, Hayden \& Thiep, 2010, p. 29), straining public resources.

Neoliberal policies to allow student choice and the market to drive decisionmaking, alongside confidence in the economy, government push for sustainable economic development and Confucian tradition on the value of education, resulted in rapid expansion of higher education both in terms of student enrollment and number of institutions. At the same, many public sectors, like higher education, had to cope with the substantial loss in government subsidies and therefore, have transferred the cost of higher education onto students and their families to. Today, about $80 \%$ of students attend overcrowded public higher educational institutions because the state absorbs $70 \%$ of the tuition; student contributions are capped at 30\% by the MOET (World Bank, 2008, Hayden \& Thiep, 2010, p. 29; also see Glewwe, et al. 1998, Glewwe and Patrinos 1999). On the other hand, students attending private universities are expected to pay the full tuition (Fry, 2009, p. 255) and yet the number of options outside of the public system is increasing each year.

The impact of neoliberal market reforms into education has questioned the purpose of education, a government-administered and societal value on education as a common good. Unforeseen and unintended consequences of blending a mixed system of public and private institutions of higher education negatively are seen, impacting both equity and efficiency. Furthermore, the transfer of costs onto students as consumers discourages excellent students from rural and poorer provinces to pursue a higher education. By allowing the market to set the agenda of public education, long recognized as a public good, higher educational institutions serve as symbolic and tangible gatekeepers for social mobility. 
Indeed rapid expansion, the World Bank (2008) noted, has caused inconsistent levels of quality within academic departments, HEIs and provincial ministries; altogether lagging behind regional and international standards. In addition in the same report, the World Bank (2008) found that Vietnam's higher education system does not adequately meet the country's increased need for innovation, research and development. Regionally, comparisons were made between Vietnam's research productivity with some of the universities in the Republic of Korea, China and Singapore (Le, 2014, p. 23), but this assessment, to me is not fair because those countries have entirely different economies, governments, colonial legacies, and destined trajectories.

Vietnam's higher education agenda has pursued privatization, marketization, commercialization and deregulation since Vietnam's opening in 1986 under Đối Mơ i. As neoliberal policies and practices have seeped into all areas of society and at all levels of education, the question remains whether the nation can absorb the impact and keep pace with economic development while improving quality and access for all learners. Secondly, the opening of Vietnam to international state and non-state actors, catalyzed after Đổi Mơ i, have significantly influenced policy and financial decision-making in all levels of education. Moreover, higher educational institutions and government policymakers continue to internationalize higher education, also seen elsewhere in the region. Considerable mention in the literature has examined the impact of post Đổi Mơ'i policy changes on access and equity in education at the primary and secondary levels, but lack of attention of neoliberal policies on tertiary education and the evident 'trickle down' negative results of these policies are left understudied and should be evaluated at both the micro and macro level.

\section{References:}

Asia Development Bank (1999). Vietnam: Country Assistance Plan, 2000-2002. Hanoi: ADB.

Australian Education International. (2012). Overview of Vietnamese Government's Decree 73/2012/ND-CP on Foreign Investment in Education and Training. Australian Government. Retrieved from https://internationaleducation.gov.au/International-network/vietnam/ PolicyUpdatesVietnam/Documents/73\%20Decree\%200n\%20Foreign\%20 Investment\%20in\%20Education\%20June\%202013.pdf

Dang, A. Q. (2009). Recent Higher Education Reforms in Vietnam: The Role of the World Bank, Denmark: Aerhus University. 
Fry, G.W. (2009). Higher Education in Vietnam. In Y. Hirosato \& Y. Kitamura (Eds.), The Political Economy of Educational Reforms and Capacity Development in Southeast Asia: Cases of Cambodia, Laos and Vietnam (p. 237-261). Dordrecht: Springer Science+Business Media B.V.

Glewwe, P. W., Dollar, D., and Litvack, J. (eds) (1998). Household Welfare and Vietnam's Transition to a Market Economy. Washington, D.C.: The World Bank.

Glewwe, P. W. and H. Patrinos (1999). The Role of the Private Sector in Education in Vietnam: Evidence from the Vietnam Living Standards Survey. World Development, 27(5), p. 887-902.

Harman, G., Hayden, N., \& Pham, T.N. (2010). Higher Education in Vietnam: Reforms, Challenges and Priorities. In G. Harman, M. Hayden, \& T. N. Pham (Eds.), Reforming Higher Education in Vietnam: Challenges and Priorities (pp. 1-14). Dordrecht: Springer Science+Business Media B.V. DOI 10.1007/978-90-481-3694-0_2.

Harman, G., Ngoc, L.T.B. (2010). In G. Harman, M. Hayden, \& T. N. Pham (Eds.), Reforming Higher Education in Vietnam: Challenges and Priorities (pp. 87-102). Dordrecht: Springer Science+Business Media B.V. DOI 10.1007/978-90-481-3694-0_2.

Hayden, M., \& Thiep, L. T. (2010). Vietnam's Higher Education System. In G. Harman, M. Hayden, \& T. N. Pham (Eds.), Reforming Higher Education in Vietnam: Challenges and Priorities (pp. 15-30). Dordrecht: Springer Science+Business Media B.V. DOI 10.1007/978-90-481-3694-0_2.

Hoang, L., Ly, T. T., \& Pham, H-H. (2018). Vietnamese Government Policies and Practices in Internationalisation of Higher Education. In L.T. Tran and S. Marginson (Eds.), Internationalisation in Vietnamese Higher Education (19-42). Cham, Switzerland: Springer

Hoang, V. Q., \& Dung, T. T. (2009). The Cultural Dimensions of the Vietnamese Private Entrepreneurship. IUP Journal of Entrepreneurship Development, 6(3/4), 54-78.

Knight, J. (2008). Higher education in turmoil: The changing world of internationalization. Rotterdam: Sense Publishers.

Lane, J. E. (2015). Higher education internationalisation: Why governments care. In E. Ullberg (Ed.), New perspectives on internationalisation and 
competitiveness (pp. 17-30). Cham: Springer International Publishing. Retrieved from https://doi.org/10.1007/978-3-319-11979-3 3.

MOET (The Ministry of Education and Training). (2002). Education Development Strategies for 2001- 2010. Hanoi: Education Publishing House.

MOET (Ministry of Education and Training). (2004). Giáo Dục Đại Họ Việt Nam [Vietnamese Higher Education]. Hanoi: Education Publishing House.

OECD (2005). Working Party on Innovation and Technology Policy: PublicPrivate Partnerships for Innovation: Synthesis Report. Paris.

Pham, L. H. and Fry. G. W. (2004). Universities in Vietnam: Legacies, challenges, and prospects. In P. G. Altbach and T. Umakoshi (Eds.), Asian Universities: Historical perspectives and contemporary challenges. Baltimore: The Johns Hopkins University.

Resolution 14/2005/NQ-CP. (2005, November 2). On fundamental and comprehensive renovation of higher education in Vietnam for the period 2006-2020 (HERA). Hanoi: Education Publishing House.

UNESCO. (2006). Higher Education in Southeast Asia. Ministry of Education and Training. Bangkok: UNESCO.

Vanham, P. (2018, September 11). The Story of Vietnam's Economic Miracle. NY Times. Retrieved from https://www.weforum.org/agenda/2018/09/howvietnam-became-an-economic-miracle/

Vuong, Q.H. (2014, May 27). Vietnam's Political Economy in Transition (19862016). Stratfor. Retrieved from https://worldview.stratfor.com/article/ vietnams-political-economy-transition-1986-2016

Weinglass, L. (2018, January 30). Asia's Latest Economic Miracle is Vietnam. World Economic Forum on ASEAN. Retrieved from https://www.nytimes.com/1990/01/30/opinion/l-asia-s-latest-economicmiracle-is-vietnam-728490.html

World Bank (2008). Vietnam: Higher Education and Skills for Growth. Washington DC: Human Development Department, East Asia and Pacific Region, The World Bank. Retrieved from http://documents.worldbank.org/curated/en/439591468338403597/pdf/ 444280ESWoWHIT1al1Julyo8020081final.pdf 